\title{
M. Knyazev
}

Institute for Linguistic Studies RAS, St. Petersburg, 199053, Russian Federation

\section{The effect of coordinate structure on the licensing of čto-clauses in noun complement constructions: An experimental study}

Previously, čto-clause complements of nouns were found to be more acceptable in constructions with collocations as opposed to non-collocations, which was taken to support the hypothesis whereby čto-clauses are introduced by a silent preposition licensed by incorporation into a complex predicate (created in collocational constructions). The paper presents the results of an acceptability rating study testing the prediction of this account, namely, that embedding the noun in a coordinate structure should block the incorporation and hence licensing of čto-clauses. In addition, an alternative hypothesis is examined according to which čto-clauses are more acceptable in collocations due to their higher frequency.

Key words: Russian, experimental syntax, noun complement clauses, collocation, coordination, frequency

FOR CITATION: Knyazev M. The effect of coordinate structure on the licensing of čto-clauses in noun complement constructions: An experimental study. Rhema. 2020. № 1. Pp. 56-69. DOI: 10.31862/2500-2953-2020-1-56-69 


\section{М.Ю. Князев}

Институт лингвистических исследований Российской академии наук, 199053 г. Санкт-Петербург, Российская Федерация

\section{Экспериментальное исследование приемлемости придаточных с союзом чmо в функции сентенциального актанта существительного в конструкциях с сочинением}

Предыдущие исследования показали, что придаточные со что при существительных более приемлемы в конструкциях с коллокациями, чем в конструкциях без коллокаций. Это может служить подтверждением ранее высказанной гипотезы о том, что такие придаточные вводятся нулевым предлогом, лицензируемым путем инкорпорации в сложный глагол в конструкциях с коллокациями. В настоящей работе приводятся результаты эксперимента на вынесение суждений о приемлемости, проверявшего предсказание данной гипотезы, согласно которому сочинительная конструкция будет блокировать инкорпорацию и тем самым приводить к неграмматичности придаточного. Также в эксперименте проверялась альтернативная гипотеза, согласно которой бо́льшая приемлемость придаточных при коллокации связана с большей частотностью последних.

Ключевые слова: русский язык, экспериментальный синтаксис, придаточные при существительных, коллокация, сочинение, частотность

ДЛЯ ЦИТИРОВАНИЯ: Князев М.Ю. Экспериментальное исследование приемлемости придаточных с союзом что в функции сентенциального актанта существительного в конструкциях с сочинением // Рема. Rhema. 2020. № 1. C. 56-69. DOI: 10.31862/2500-2953-2020-1-56-69 


\section{Introduction}

Like their English counterparts, declarative sentential complements in Russian (čto-clauses) can appear not only in direct (nominative subject / accusative object), but also in oblique/PP positions, where they alternate with the $(\mathrm{P}+)$ to + ctto-clause construction (to,čto-clauses), which consists of the demonstrative to 'that' case-marked by $\mathrm{P}$ or $\mathrm{V}$ and followed by a čtoclause, as shown in (1a).

(1) Ona uverena (v tom), čto on pridet. she.NOM certain in it.LOC that he will come

Previous work aimed to uncover semantic/grammatical factors governing the choice between the two clause types [Knyazev, 2016] found that there is a strong preference to realize complements of nominalizations like 'hope', 'conviction', etc. and of relational nouns such as 'likelihood', etc. as to,čtoclauses (but not čto-clauses) unless the noun forms a 'set collocation' with the higher verb (in which case both clause types are possible), cf. collocation 'express conviction' in (2a) vs. non-collocation 'strengthen (one's) conviction' in $(2 b){ }^{1}$

(2) a. Collocation

$\begin{array}{lllll}\text { Ona } & \text { vyrazila } & \text { uverennost } & \text { (v } & \text { tom), } \\ \text { she.NOM } & \begin{array}{c}\text { expressed } \\ \text { conviction.ACC }\end{array} & \text { in } & \text { it.LOC } \\ \text { čto on } & \text { pridet. } & & & \\ \text { that he } & \text { will come } & & & \end{array}$

b. NON-COLLOCATION

$\begin{array}{lllll}\text { Èto } & \text { usililo } & \text { uverennost' } & \text { ??(v } & \text { tom }) \text {, } \\ \text { this } & \text { strengthened } & \text { conviction.ACC } & \text { in } & \text { it.LOC } \\ \text { čto } & \text { on } \quad \text { pridet. } & & & \\ \text { that } & \text { he } \quad \text { will come } & & & \end{array}$

The contrast in (2), referred to as the 'collocational restriction' (on čtoclause complements of nouns), was later tested in an acceptability rating study [Knyazev, to appear a] using a $2 \times 2$ factorial design crossing factors CLAUSE TYPE and (NON-)COLLOCATION, following experimental work on island effects [Sprouse et al., 2016]. In that experiment, which contrasted 12 collocations and non-collocations of the same $\mathrm{N}$, as in (2), a (super-additive) interaction was found showing that, although čto-clauses were associated with a decrease in acceptability relative to to,čto-clauses in both constructions, this decrease was 0.43 points greater in the non-collocational constructions.

${ }^{1}$ For further discussion of the contrast between $\check{c} t o-$ and to,čto-clauses see [Kobozeva, 2013]. 
These results were taken to support the grammatical account of the collocational restriction proposed in [Knyazev, 2016], according to which:

a) to,čto-clauses in oblique/PP positions are introduced by a silent preposition, which must be licensed by abstract incorporation into a higher verb;

b) the noun can reanalyze with the verb to form a complex verb only in collocational constructions.

Given the logic of experimental syntax studies such as [Sprouse et al., 2016], the decrease in acceptability of čto-clauses in non-collocational constructions can be explained by a (grammatical) violation of the licensing conditions associated with silent $P$.

Although the experimental results are consistent with the proposed grammatical account, they are not conclusive as the collocations and noncollocations (within a sentence set) in the experiment above differed widely along various dimensions including broad semantics and frequency. For example, one cannot exclude an alternative hypothesis according to which čto-clauses are simply stored in memory along with associated V-N combinations in an item-based fashion, whereas to,čto-clauses are fully productive and depend only on the semantics of the construction (henceforth, the "frequency hypothesis"). The frequency hypothesis would predict a contrast in acceptability for čto-clauses between collocational V-N combinations, which are more frequent, and non-collocational ones, which are less frequent, but no contrast for to,čto-clauses. This difference would result in a super-additive interaction.

This hypothesis was tested in [Knyazev, to appear b], which contrasted 12 pairs of semantically similar collocations with a higher vs. lower corpus frequency (e.g., vyrazit' uverennost' 'express conviction' vs. vyskazat' uverennost' 'voice hope') using a forced-choice task. Although the results showed no effect of frequency and hence no support for a frequency-based account, the difference in the design of this experiment from the design of the experiment in [Knyazev, to appear a], makes it hard to compare the two experiments directly. Moreover, in a follow-up analysis a marginal correlation was found between the proportion of čto-clause responses and the log frequency of $\mathrm{V}-\mathrm{N}$, suggesting that frequency might still play some role in acceptability.

In view of the limitations of the studies reported above, a more direct way of testing the predictions of the account in [Knyazev, 2016] is called for. In particular, the account predicts that if incorporation of silent $\mathrm{P}$ (by hypothesis, introducing a čto-clause) is blocked by some syntactic configuration such as embedding in a coordinate structure, a čto-clause 
will become ungrammatical. In addition, a frequency-based account must be tested within the same design in order to be able to directly compare the two effects. This paper reports the results of an acceptability rating study which (in a single design) simultaneously tested the effects of embedding the noun in a coordinate structure and the effect of frequency of the V-N collocation on the acceptability of čto-clauses.

The paper is structured as follows. In section 2 the main competing hypotheses are introduced, and the design of the experiment is discussed. Section 3 discusses the materials and the procedure used in the experiment. Section 4 presents and discusses the results of the experiment. Section 5 concludes.

\section{The hypotheses and design}

\subsection{The coordination hypothesis}

According to [Knyazev, 2016], čto-clause complements are underlyingly nominal expressions and are subject to the Case Filter. The crucial assumption of the account is that in apparent 'Caseless' positions, e.g., those associated with oblique/PP selecting verbs, čto-clause are licensed by the silent preposition $\mathrm{P}_{\text {HOLD }}$, which has the semantics of the relation of holding propositional content. It is further assumed that $\mathrm{P}_{\mathrm{HOLD}}$ must incorporate into a verbal head in order to get licensed (the incorporation has the semantic effect of predicate conjunction). Assuming that in collocational V-Ns such as (2a), N itself can abstractly incorporate into $\mathrm{V}$ to create a complex predicate (cf. the analysis of make the claim in [Davies, Dubinsky, 2003]), $\mathrm{P}_{\mathrm{HOLD}}$ associated with such $\mathrm{V}-\mathrm{Ns}$ will be licensed by virtue of incorporation into this complex predicate, as schematized in (3a). ${ }^{2}$ By contrast, in non-collocational V-N, as in (2b), no complex predicate will be created and thus $\mathrm{P}_{\mathrm{HOLD}}$ and the čto-clause will fail to be licensed.

This account predicts that even in collocational V-N such as (2a) whenever incorporation of $\mathrm{N}$ to $\mathrm{V}$ is disrupted, a complex predicate will fail to be created, thus blocking licensing of the čto-clause. One such configuration is coordinate structure, generally taken to be an island for movement (including incorporation). The prediction then is that if the complementtaking $\mathrm{N}$ is conjoined with a noun phrase (xNP), the incorporation of this $\mathrm{N}$ (or, more precisely, the $\mathrm{P}_{\mathrm{HOLD}}+\mathrm{N}$ complex) into $\mathrm{V}$ will be blocked, leading to ungrammaticality, as in (3b).

\footnotetext{
${ }^{2}$ According to standard assumptions, this process must proceed cyclically. First, $\mathrm{P}_{\text {HOLD }}$ incorporates into $\mathrm{N}$ and then the $\left[\mathrm{P}_{\mathrm{HOLD}}+\mathrm{N}\right]$ complex incorporates into $\mathrm{V}$.
} 


\section{(3) a. $\left[{ }_{\mathrm{V}^{\prime}}\left[\left[\mathrm{P}_{\mathrm{HOLD}}+\mathrm{N}\right]+\mathrm{V}\right]\left[_{\mathrm{NP}}\left[\mathrm{P}_{\mathrm{HOLD}}+\mathrm{N}\right]\left[_{\mathrm{PP}} \mathrm{P}_{\mathrm{HOLD}}\left[{ }_{\mathrm{xNP}}\right.\right.\right.\right.$ čto... $\left.\left.]\right]\right] \quad(=(2 \mathrm{a}))$ \\ b. $*\left[{ }_{\mathrm{V}^{\prime}} \mathrm{V}\left[\mathrm{xNP} \&\left[\left[_{\mathrm{NP}}\left[\mathrm{P}_{\mathrm{HOLD}}+\mathrm{N}\right]\left[{ }_{\mathrm{PP}} \mathrm{P}_{\mathrm{HOLD}}\left[{ }_{\mathrm{xNP}}\right.\right.\right.\right.\right.\right.$ čto... $\left.\left.\left.]\right]\right]\right]$

To test this hypothesis, examples like (4), with coordination, were contrasted with examples like (2a) above, without coordination. Given the logic of the previous studies [Knyazev, to appear a], the prediction is that in examples like (2a), čto-clauses will lead to a greater decrease in acceptability (relative to to,čto-clauses) than in examples like (4), which is equivalent to a non-zero (positive) difference between the differences between čto and to, čto in the two conditions, so-called "difference-in-differences", or DD, which can be viewed as the measure of the "coordination effect", as shown in (5), see [Sprouse et al., 2016]. In statistical terms, this hypothesis predicts a (super-additive) interaction between the factors \pm COORDINATION and CLAUSE TYPE (to, čto vs. čto).

(4) Ona

vyrazila

[ljavnoe

nedoumenie] i

[uverennost'

she.NOM expressed obvious

puzzlement and ?? (v tom),

čto

on

pridet]].

in it.LOC that he will come

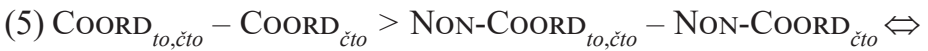

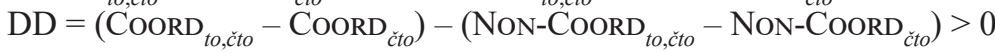

\subsection{The frequency hypothesis}

According to the frequency hypothesis, discussed in [Knyazev, to appear b], the contrast between examples with collocational V-N in (2a) and non-collocational V-N in (2b) follows from the higher token frequency of the former. In accordance with usage-based approaches, the hypothesis assumes that experience (operationalized as token frequency) plays an important role in the acquisition of and mature competence with particular constructions. Crucially, it is further assumed that the effect of token frequency is modulated by higher "regularity" of the construction (operationalized as a higher type frequency) so that more regular constructions are less affected by token frequency (as compared to construction with a lower type frequency) as they are less dependent on experience. This leads to what has been described as Regularity $\times$ Frequency interactions [Christiansen, Chater, 2016]. Assuming that čto-clauses in oblique/PP positions are less regular than to,cto-clauses, they will be more strongly affected by the higher frequency of V-N ("frequency effect"), as shown in (6), accounting for the contrast between collocational and non-collocational V-N in $(2 a)-(2 b)$. 


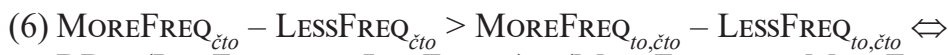
$\mathrm{DD}=\left(\operatorname{LesSFREQ}_{t o, \check{c t o}}-\operatorname{LESSFREQ}_{\check{c t o}}\right)-\left(\mathrm{MOREFREQ}_{t o, \check{c t o}}-\mathrm{MOREFREQ}_{\check{c t o}}\right)>0$

The frequency hypothesis in (6) further predicts that the same contrast will be obtained between collocational V-N with higher vs. lower token frequencies (in construction with čto-clauses). To test this hypothesis, collocations like (2a) were contrasted with semantically and structurally identical collocations with lower frequency, as shown in (7). In statistical terms, this hypothesis predicts a (super-additive) interaction between factors FREQUENCY and CLAUSE TYPE.

$\begin{array}{lllll}\text { (7) Ona } & \text { vyskazala } & \text { uverennost' } & \text { (v } & \text { tom), } \\ \text { she.NOM } & \begin{array}{c}\text { voiced } \\ \text { conviction.ACC }\end{array} & \text { in } & \text { it.LOC } \\ \text { čto on } & \text { pridet. } & & & \\ \text { that he } & \text { will come } & & & \end{array}$

Note that the contrast between (2a) and (7), should it occur, is not predicted by the grammatical account in (3), as both types of V-Ns are presumably derived by incorporation. Similarly, the contrast between (2a) and (4) is not predicted by the frequency hypothesis (at least without modification) as they involve the same surface strings " $\mathrm{V}+\mathrm{N}+\check{c} t o$ ". Thus, the results of the experiment will allow to decide which hypothesis is more consistent with the data.

\section{Materials and procedure}

The experimental items consisted of twelve sets of six lexically matched sentences given in Table 1. Each set included a pair of V-N collocations which were semantically and structurally similar but differed in frequency as well as one coordinated collocation based on the more frequent $\mathrm{V}-\mathrm{N}$, each with a čto- and a to,čto-clause. The pairs of collocations were selected based on a prior corpus study in such a way that the higher frequency V-Ns had a higher token frequency of čto-clauses, see Table $2 .^{3}$ The coordinated collocations were constructed by (left-)conjoining the noun in the collocation by some semantically appropriate noun modified by an adjective. In order to exclude an analysis with coordination between $\mathrm{N}$-heads, nouns that disallow a čto-clause in this construction were chosen as the first $\mathrm{N}$. Additionally, the two Ns typically differed in gender and/or most adjectives were semantically incompatible with the second $\mathrm{N}$. The actual sentences that participants rated were constructed by slightly modifying naturally occurring examples found on the Web. ${ }^{4}$

\footnotetext{
${ }^{3}$ The corpus study was based on the texts written after 1950 in the Russian National Corpus (RNC), ruscorpora.ru. See [Knyazev, to appear b] for details.

${ }^{4}$ Experimental sentences based on nine pairs of high vs. lower frequency V-Ns in Table 1 (sets 1-9) were directly taken from [Knyazev, to appear b].
} 
The experimental sentences were divided into six lists in a Latin square design and interspersed with 24 fillers with different syntactic structures (8 grammatical, 8 ungrammatical and 8 of intermediate acceptability). Participants were instructed to rate the naturalness of experimental sentences on a 7-point scale (1 indicating a totally unnatural-sounding sentence). The experiment was hosted on Google Forms and advertised via social media. One hundred and seventy-five people participated in the experiment; their mean age was 28.05 (range: 16-62).

Table 1

Materials used in the experiment

\begin{tabular}{|c|c|c|}
\hline & MoreFrequent/LESSFrEQUENT & COORdinated \\
\hline 1 & $\begin{array}{l}\text { byla/ostavalas' nadežda } \\
\text { 'was / was left hope' }\end{array}$ & $\begin{array}{l}\text { byl oxotničij azart i nadežda } \\
\text { 'was wild excitement and hope' }\end{array}$ \\
\hline 2 & $\begin{array}{l}\text { pojavilas'/zarodilas' nadežda } \\
\text { 'appeared / was born hope' }\end{array}$ & $\begin{array}{l}\text { pojavilas' finansovaja podderžka } \boldsymbol{i} \\
\text { nadežda } \\
\text { 'appeared financial support and hope' }\end{array}$ \\
\hline 3 & $\begin{array}{l}\text { vyrazil/vyskazal nadeždu } \\
\text { 'expressed/voiced hope' }\end{array}$ & $\begin{array}{l}\text { vyrazil sderžannyj optimizm } \boldsymbol{i} \text { nadeždu } \\
\text { 'expressed restrained optimism and } \\
\text { hope' }\end{array}$ \\
\hline 4 & $\begin{array}{l}\text { daet/darit nadeždu } \\
\text { 'gives/presents hope' }\end{array}$ & $\begin{array}{l}\text { daet moral'noe udovletvorenie } \boldsymbol{i} \\
n a d e z ̌ d u \\
\text { 'gives moral satisfaction and hope' }\end{array}$ \\
\hline 5 & $\begin{array}{l}\text { poterjal/poxoronil nadeždu } \\
\text { 'lost/buried hope' }\end{array}$ & $\begin{array}{l}\text { poterjala byloj èntuziazm i nadeždu } \\
\text { 'lost former enthusiasm and hope' }\end{array}$ \\
\hline 6 & $\begin{array}{l}\text { est'/soxranjaetsja uverennost' } \\
\text { 'is/remains conviction' }\end{array}$ & $\begin{array}{l}\text { est' položitel'nyj nastroj i uverennost' } \\
\text { 'is positive attitude and conviction' }\end{array}$ \\
\hline 7 & $\begin{array}{l}\text { pojavilas'/voznikla uverennost' } \\
\text { 'appeared/emerged conviction' }\end{array}$ & $\begin{array}{l}\text { pojavilos' duševnoe spokojstvie i } \\
\text { uverennost' } \\
\text { 'appeared peace of mind and conviction' }\end{array}$ \\
\hline 8 & $\begin{array}{l}\text { vyrazil/vyskazal uverennost' } \\
\text { 'expressed/voiced conviction' }\end{array}$ & $\begin{array}{l}\text { vyrazil javnoe nedoumenie i } \\
\text { uverennost' } \\
\text { 'expressed obvious puzzlement and } \\
\text { conviction' }\end{array}$ \\
\hline 9 & $\begin{array}{l}\text { est'/imejutsja dokazatel'stva } \\
\text { 'are/exist proofs' }\end{array}$ & $\begin{array}{l}\text { est' ustanovlennye fakty } \boldsymbol{i} \\
\text { dokazatel 'stva } \\
\text { 'are established facts and proofs' }\end{array}$ \\
\hline 10 & $\begin{array}{l}\text { bylo/ostavalos' somnenie } \\
\text { 'was / was left doubt' }\end{array}$ & $\begin{array}{l}\text { byla smutnaja trevoga i somnenie } \\
\text { 'was vague anxiety and doubt' }\end{array}$ \\
\hline 11 & $\begin{array}{l}\text { vozniklo/pojavilos' somnenie } \\
\text { 'appeared/emerged doubt' }\end{array}$ & $\begin{array}{l}\text { vozniklo nexorošee podozrenie } \boldsymbol{i} \\
\text { somnenie } \\
\text { 'emerged nasty suspicion and doubt' }\end{array}$ \\
\hline 12 & $\begin{array}{l}\text { vyrazil/vyskazal somnenie } \\
\text { 'expressed/voiced doubt' }\end{array}$ & $\begin{array}{l}\text { vyrazil krajnij skepticism i somnenie } \\
\text { 'expressed extreme skepticism and } \\
\text { doubt' }\end{array}$ \\
\hline
\end{tabular}


Table 2

Frequencies of čto- and a to,čto-clauses with more and less frequent collocations (RNC)

\begin{tabular}{|c|c|c|c|c|c|c|c|c|c|}
\hline \multirow{2}{*}{ set } & \multicolumn{2}{|c|}{$\mathrm{V}-\mathrm{N}_{\text {MoReFreQ }}$} & \multicolumn{2}{|c|}{ V-N LessFreq } & \multirow{2}{*}{ set } & \multicolumn{2}{|c|}{ V-N ${ }_{\text {MoREFreQ }}$} & \multicolumn{2}{|c|}{ V-N LessFreQ $_{\text {e }}$} \\
\hline & čto & to, čto & čto & to, čto & & čto & to, čto & čto & to, čto \\
\hline 1 & 255 & 42 & 41 & 11 & 7 & 23 & 2 & 8 & 1 \\
\hline 2 & 42 & 6 & 8 & 0 & 8 & 104 & 40 & 17 & 6 \\
\hline 3 & 156 & 25 & 15 & 1 & 9 & 29 & 12 & 5 & 2 \\
\hline 4 & 24 & 18 & 0 & 3 & 10 & 114 & 75 & 49 & 25 \\
\hline 5 & 38 & 8 & 0 & 2 & 11 & 25 & 20 & 5 & 4 \\
\hline 6 & 147 & 29 & 1 & 1 & 12 & 15 & 19 & 6 & 13 \\
\hline
\end{tabular}

\section{Results and discussion}

\subsection{Overall results}

The ratings were z-score transformed in accordance with the usual practice in experimental syntax [Sprouse et al., 2016]. Grammatical fillers received the (transformed) rating of $0.61(\mathrm{SD}=0.66)$, ungrammatical fillers the rating of $-1.12(\mathrm{SD}=0.51)$ and fillers of intermediate acceptability the rating of $-0.4(\mathrm{SD}=0.88)$. The (transformed) condition means are given in Table 3 .

Table 3

\section{Z-score means (SD) in the experiment}

\begin{tabular}{|l|c|c|}
\hline & to, čto & čto \\
\hline COORD & $0.62(0.70)$ & $0.17(0.70)$ \\
\hline NoNCOORD/MOREFreQ & $0.87(0.46)$ & $0.52(0.63)$ \\
\hline LESSFREQ & $0.81(0.52)$ & $0.51(0.62)$ \\
\hline
\end{tabular}

The ratings were entered into a linear mixed-effects model with clause type, construction type and their interaction as fixed effects. Construction type was treatment coded with more frequent/non-coordinated V-N as the baseline contrasted with less frequent and coordinated V-N. Following [Barr et al., 2013], a maximal random effect structure that allowed convergence was used. ${ }^{5}$

${ }^{5}$ The model included random by-subject slopes for clause type and construction type, random item intercept and random by-item slopes for clause type and construction type and their interaction. $P$-values were obtained using Satterthwaite approximation from the lmerTest package for $\mathrm{R}$. 
The model revealed a main effect of clause type such that sentences with čto-clauses were rated lower than sentences with to,čto-clauses (Estimate $=-0.35, \mathrm{SE}=0.07, t=-5.10, p<0.001)$. The model also revealed a main effect of construction type such that sentences with coordination were rated lower than sentences with non-coordinated/more frequent collocations. (Estimate $=-0.25, \mathrm{SE}=0.06, t=-3.48, p<0.004)$. Interestingly, no interaction between clause type and construction type was observed as shown by the fact that the coefficients for both interaction terms in the model output were not significantly different from zero ( $\breve{\text { TO }} *$ LessFreQ: Estimate $=0.06, \mathrm{SE}=0.06$, $t=0.89, p=0.39$; С̆то $*$ CoORD: Estimate $=-0.11, \mathrm{SE}=0.08, t=-0.38$, $p=0.19)$. These results are plotted in Fig. 1 .

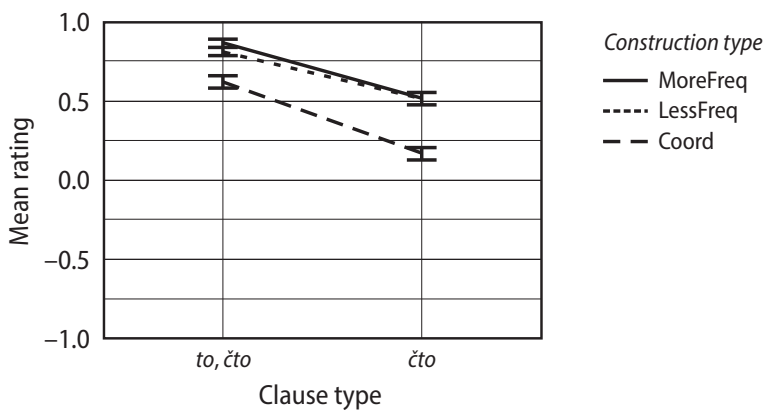

Fig. 1. Z-score means (SE) in the experiment

\subsection{Results by items: Coordination}

Although the interaction between coordination and clause type was not significant, we see a numerical trend in the predicted direction, i.e., čto-clauses were associated with a 0.11 points greater decrease in acceptability in the coordination condition. Thus, it was decided to inspect individual sets, as shown in Table 4.

Four out of 12 items (sets 1, 6, 8 and 12), shaded in Table 4, showed a positive $\mathrm{DD}_{\text {Coord }}$, as defined in (5), with range $0.33-0.48$, which is above the minimal threshold for island effects $(=0.25)$ in [Kush et al., 2018]. ${ }^{6}$ In addition, set 7 showed a $\mathrm{DD}_{\text {Coord }}$ close to this threshold $(0.20)$. One interesting feature that these sets share is that they are precisely those that showed the smallest effect of čto-clause $(-0.02-0.25)$, shown in bold, operationalized as the difference between to,čto- and čto-clauses in the baseline condition (С̌Tо.ЕFFECT).

${ }^{6}$ Since there is no standardly accepted threshold for a grammatical (interaction) effect [Sprouse et al., 2016], the threshold suggested in [Kush et al., 2018] was used. 
This observation was confirmed by a strong negative correlation between $\mathrm{DD}_{\text {Coord }}$ and the effect of čto-clause $(r=-0.89, p<0.001)$, suggesting that a stronger decrease shown by cto-clauses in the baseline condition is associated with a weaker effect of coordination. By contrast, there was no correlation between $\mathrm{DD}_{\text {CоoRD }}$ and the (independent) effect of coordination (COORD.EFFECT), operationalized as the difference between coordinated and non-coordinated collocations in the to, čto condition $(r=0.12, p=0.69){ }^{7}$

Table 4

\section{Experimental effects by items}

\begin{tabular}{|c|c|c|c|c|c|c|c|}
\hline set & $\begin{array}{l}\text { С̆то. } \\
\text { ЕFFECT }\end{array}$ & $\begin{array}{c}\text { ČTo. } \\
\text { LESSFrEQ }\end{array}$ & $\begin{array}{l}\text { Čто. } \\
\text { COORD }\end{array}$ & $\begin{array}{l}\text { FreQ. } \\
\text { EFFECT }\end{array}$ & $\begin{array}{l}\text { COORD. } \\
\text { EFFECT }\end{array}$ & DD $_{\text {FREQ }}$ & DD $_{\text {COORD }}$ \\
\hline 1 & -0.02 & 0.01 & 0.33 & 0.10 & 0.19 & 0.03 & 0.35 \\
\hline 2 & 0.41 & 0.23 & 0.36 & 0.34 & 0.09 & -0.18 & -0.05 \\
\hline 3 & 0.52 & -0.02 & 0.54 & 0.09 & 0.06 & -0.54 & 0.02 \\
\hline 4 & 0.50 & 0.41 & 0.48 & 0.01 & 0.07 & -0.09 & -0.02 \\
\hline 5 & 0.92 & 0.74 & 0.39 & 0.03 & 0.15 & -0.18 & -0.53 \\
\hline 6 & 0.08 & 0.48 & 0.41 & -0.24 & 0.10 & 0.40 & 0.33 \\
\hline 7 & 0.15 & 0.38 & 0.35 & 0.02 & 0.09 & 0.23 & 0.20 \\
\hline 8 & 0.22 & 0.18 & 0.70 & 0.22 & 0.58 & -0.04 & 0.48 \\
\hline 9 & 0.35 & 0.14 & 0.38 & 0.11 & 0.35 & -0.21 & 0.03 \\
\hline 10 & 0.43 & 0.12 & 0.40 & 0.26 & 0.58 & -0.31 & -0.03 \\
\hline 11 & 0.47 & 0.53 & 0.54 & -0.07 & 0.63 & 0.06 & 0.07 \\
\hline 12 & 0.25 & 0.45 & 0.66 & -0.10 & 0.13 & 0.20 & 0.41 \\
\hline
\end{tabular}

\subsection{Results by items: Frequency}

By-item DD-scores for the interaction between frequency and clause type $\left(\mathrm{DD}_{\mathrm{FREQ}}\right)$, cf. (7), were inspected in a similar way. In this case we see little evidence for any interactions: only set 6 showed an effect greater than 0.25 (0.40); in addition, two others (sets 7 and 12) showed an effect of 0.20-0.23.

7 At first glance, the negative correlation between $\mathrm{DD}_{\text {COoRD }}$ and the effect of ćtoclause is expected given that $\mathrm{DD}_{\text {СоовD }}$ is calculated by substracting the effect of cto-clause (in the baseline condition) from the effect of cto-clause in the coordinated condition, cf. (5). Note, however, that this is only the case if the latter effect is constant, which need not be the case. Note also that $\mathrm{DD}_{\text {СоовD }}$ is also equivalent to the difference between the effect of coordination in the ctocondition and the effect of coordination (in the to, čto condition), i.e., COORD.EFFECT, as in (i). Yet, there was no correlation between $\mathrm{DD}_{\text {Coord }}$ and COORD.EFFECT. 
There does not seem to be any clear property that sets these sets apart. Yet, we also see a marginally significant negative correlation between the effect of čto-clause and $\mathrm{DD}_{\text {FREQ }}(r=-0.59, p=0.05)$, suggesting that the frequency effect is somewhat stronger for those sets that have a weaker effect of čtoclause in the baseline (more frequent) condition.

Since frequency was treated as a categorical variable, the difference in frequency between particular pairs of collocations in the experiment might have been too small to lead to a visible effect. Therefore, it was decided to test whether there is association between the log frequency of a collocation in construction with a čto-clause (see Table 2), and the effect of čto-clause for all 24 collocations (union of ČTO.MoreFrEQ and ČTO.LESSFrEQ), ignoring the fact the collocations were matched in the experiment. This correlation was not significant $(r=-0.33, p=0.11)$. However, the (negative) correlation between the proportion of čto-clause and the effect of čto-clause did reach significance $(r=-0.44, p=0.03)$, suggesting that collocations with a higher proportion of čto-clauses tend be less effected by the decrease in acceptability associated with čto-clauses.

\subsection{Discussion}

Overall, the experiment did not provide evidence for the effect of coordination (operationalized as a super-additive interaction between coordination and clause type). While there were independent lowering effects of both čto-clause and coordination, there was no decrease in acceptability of čto-clauses with coordination above and beyond those effects (i.e., we see a linear additive effect). Thus, the results fail to provide direct support for the grammatical account in (3). Nonetheless, 4 to 5 out of 12 items were associated with a stronger decrease in acceptability of čto-clauses in the coordination condition (0.33-0.48), as compared to the baseline. In addition, all items showed a stable lowering effect of čto-clause in the coordination condition (0.33-0.70), see column C̆то.CoORD in Table 4. Given the operationalization of the coordination effect in (5), it is possible that this effect was "artificially" reduced by an independent effect of cto-clause. This interpretation is supported by the fact that the coordination effect is seen precisely in those V-Ns that do not show an effect of čto-clause, suggesting that it is somehow "absorbed" by the effect of čtoclause, see [Hofmeister et al., 2014] for some discussion. This raises questions about how the coordination effect should be operationalized. Perhaps it should be defined factorially (see [Sprouse et al., 2016]) only when other effects are not simply controlled for but cancelled (i.e., when there is no independent effect of cto-clause). Or perhaps it should be defined in relative rather than factorial terms (i.e., as the effect of čto-clause in the coordinated condition). These questions are left for future work. 
As for the frequency hypothesis, the results provide little evidence for it. Apart from the lack of interaction between frequency and clause type, only 1 to 3 items out of 12 (with no clear pattern) showed any effect. Moreover, the effect of čto-clause was not consistently observed in the less frequent condition (see column ČTO.LessFreQ in Table 4). While this might be due to a particular choice of materials so that a higher contrast in frequency might lead to a stronger effect, on the whole, frequency remains an unlikely source of the previously reported super-additive interaction, in accord with [Knyazev, to appear b].

\section{Conclusion}

I have examined two potential explanations for the so-called collocational restriction, according to which čto-clause complements of nouns are associated with a higher decrease in acceptability (relative to to,čto-clauses) if the noun belongs to a V-N collocation [Knyazev, to appear a]. Namely, (a) the grammatical account, whereby čto-clauses are introduced by a null preposition licensed by incorporation into a complex verbal head created in collocational constructions; and (b) the frequency account, according to which collocations have a higher frequency, affecting the acceptability of čto-clauses (but not to,čto-clauses). The study focused on the specific prediction of the grammatical account, according to which coordination should block incorporation of the null preposition and thus "unlicense" čto-clauses. These two hypotheses were tested in an acceptability study with a factorial design crossing factors construction type (more frequent/ non-coordinated vs. less frequent vs. coordinated collocations) and clause type (to,čto- vs. čto-clauses), where both hypotheses were operationalized as a super-additive interaction as in [Sprouse et al., 2016]. While the results did not provide direct support for either account, there is indirect evidence that the coordination effect was obscured by an independent effect of čtoclause, suggesting that coordination effect might be restricted to those collocations that are equally acceptable with čto- and to,čto-clauses.

\section{References}

Barr et al., 2013 - Barr D.J., Levy R., Scheepers C., Tily H.J. Random effects structure for confirmatory hypothesis testing: Keep it maximal. Journal of Memory and Language. 2013. Vol. 68. No. 3. Pp. 255-278.

Christiansen, Chater, 2016 - Christiansen M.H., Chater N. Creating Language. Cambridge, MA, 2016.

Davies, Dubinsky, 2003 - Davies W., Dubinsky S. On extraction from NPs. Natural Language \& Linguistic Theory. 2003. Vol. 21. No 1. Pp. 1-37. 
Hofmeister et al., 2014 - Hofmeister P., Staum Casasanto L., Sag I.A. Processing effects in linguistic judgment data: (super-)additivity and reading span scores. Language and Cognition. 2014. Vol. 6. No. 1. Pp. 111-145.

Knyazev, 2016 - Knyazev M. Licensing clausal complements: The case of čtoclauses. PhD diss., Utrecht University. 2016.

Knyazev, to appear a - Knyazev M. An experimental study of the distributional restriction on Russian čto-clause complements of nouns. Proceedings of FASL 26. To appear.

Knyazev, to appear b - Knyazev M. Frequency as a (non)-predictor of acceptability: Russian V-N collocations with čto-clause complements. Proceedings of FASL 27. To appear.

Kush et al., 2018 - Kush D., Lohndal T., Sprouse J. Investigating variation in island effects: A case study of Norwegian. Natural Language \& Linguistic Theory. 2018. Vol. 36. No. 3. Pp. 746-779.

Kobozeva, 2013 - Кобозева И.М. Условия употребления «то» перед придаточным изъяснительным с союзом «что» // Du mot au texte. Études slavo-romanes / Под ред. О. Инковой. Bern, 2013. С. 131-150. [Kobozeva I.M. Terms of use to before the subjunctive with the conjunction čto. Du mot au texte. Études slavoromanes. O. Inkova (ed.). Bern, 2013. Pp. 131-150. (In Russ.)]

Sprouse et al., 2016 - Sprouse J., Caponigro I., Greco C., Cecchetto C. Experimental syntax and the variation of island effects in English and Italian. Natural Language \& Linguistic Theory. 2016. Vol. 34. No. 1. Pp. 307-344.

Статья поступила в редакцию 10.11.2019, принята к публикации 15.12.2019

The article was received on 10.11.2019, accepted for publication 15.12.2019

\section{Об авторе / About the author}

Князев Михаил Юрьевич - PhD (лингвистика); научный сотрудник Отдела теории грамматики, Институт лингвистических исследований Российской академии наук, г. Санкт-Петербург

Mikhail Yu. Knyazev - PhD in Linguistics; Researcher at the Department of Grammar Theory, Institute for Linguistic Studies RAS, St. Petersburg, Russian Federation

ORCID: http://orcid.org/0000-0003-4652-4144

E-mail: misha.knjazev@gmail.com 